\title{
Sovereignty and National Civil Procedure: An Analysis of State Practice in Japan
}

\author{
Keisuke Takeshita*
}

Advanced telecommunication technologies enable us to employ new methods for judicial acts in the national civil procedure, such as facilitating evidence through a video-link system. However, before implementing these methods in the national proceedings for cases with foreign elements, it is necessary to elucidate the relationship between sovereignty and judicial acts of courts, including the validation of these new methods. This is because judicial acts by courts are considered to fall within the purview of the exercise of sovereignty from a Japanese perspective. From the analysis on Japanese state practices to date, it is recognized that Japan has strictly abided by the principle of territoriality under public international law. Nevertheless, reconsidering the meaning of sovereignty, Japan can adopt a more liberal and tolerant policy. In particular, Japan can become more tolerant of other countries' judicial acts, which may be conducive to the better delivery of justice in transnational civil and commercial dispute settlements.

\section{Keywords}

Sovereignty, Civil Procedure, State Practice, Japan, Service of Process

* Associate Professor of Law at Hitotsubashi University, Tokyo, Japan. LL.B. (Tokyo). ORCID: http://orcid.org/00000002-5936-551X. The author may be contacted at: kei.takeshita@r.hit-u.ac.jp/Address: Hitotsubashi University School of Law, 2-1, Naka, Kunitachi, Tokyo 186-8601 Japan.

DOI: http://dx.doi.org/10.14330/jeail.2016.9.2.03 


\section{Introduction}

In Japan, one of the current issues before private lawyers is sovereignty in the national civil procedure. ${ }^{1}$ From the Japanese perspective, individual judicial acts of courts effecting national civil procedures, such as the service of process and the procedure of obtaining evidence by a court, are considered exercises of sovereignty. ${ }^{2}$ A national court should not infringe on other states' sovereignty in carrying out such acts when handling a case with foreign elements, such as a defendant resident in a foreign country.

Technological developments especially in the area of information and communication enable us to employ novel methods for judicial acts. E.g., parties and witnesses can be examined via a video-link system. ${ }^{3}$ These methods certainly facilitate court proceedings, and parties in such proceedings benefit from their use. Although the Japanese Code of Civil Procedure (hereinafter the Code) provides judicial acts using these technologies, ${ }^{4}$ such methods are currently only available for judicial acts within Japan. ${ }^{5}$ It is certainly true that new technologies are more valuable for cases with foreign elements than for purely domestic ones. As a result, some Japanese lawyers have advocated the application of these methods in Japanese court proceedings for the cases involving foreign elements. ${ }^{6}$ Nevertheless, before implementing these new methods in national proceedings for cases with foreign elements, it is necessary to elucidate how these methods affect other states' sovereignty not to infringe it.

The primary purpose of this research is to introduce and analyze Japanese state practice regarding sovereignty and national civil procedure. First, Japanese state practice regarding the service of process from Japanese courts upon foreign-residing persons, and upon residents in Japan will be introduced. Then, Japanese state

1 Kyoko Hijikata, Service of Process and Taking Evidence in Cases Where a Party is in Foreign Country 当事者や証拠 が外国に存在する場合の送達及び証拠調べ, 67 (5) LIBERTY \& JUSTICE 自由と正義 13 (2016).

2 Civil Affairs Bureau in General Secretariat of Supreme Court 最高裁判所事務総局 ed., HANDBOOK OF PROCEDURE FOR InTERNATIONAL CIVIL CASES 国際民事事件手続ハンドブック5 (2013).

3 Hague Conference on Private International Law (HCCH), Practical Handbook on the Operation of the Evidence Convention 279-82 (3d ed. 2016).

4 The Code arts. 170 (3), 204 \& 215. See An English translation of the Japanese law, available at http://www. japaneselawtranslation.go.jp/?re=02 (last visited on Nov. 11, 2016).

5 The video-conference system for Japanese court proceedings only enables connections between the rooms of Japanese courts specially equipped for use of the system. See Yoshiyuki Mori et al., Examination of witnesses through Video Conference System テレビ会議システムによる証人などの尋問, 986 LAW TIMES REPORTS 判例タイムズ 111 (1999).

6 Supra note 1 , at 19-20. 
practice on taking evidence abroad will be explained. Finally, the author will analyze discussions on these state practices and explore questions of sovereignty in relation to national civil procedure.

\section{Service of Process to and from Japan}

\section{A. Service of Process by Japanese Courts upon Foreign Residents}

Japanese law regards the service of process as an exercise of sovereignty. In particular, it is recognized as an exercise of the "jurisdiction to enforce." If a Japanese court needs to realize the service of process upon a person in a foreign country, it cannot not directly do so without the consent or support of that foreign country because of the territoriality principle of the jurisdiction to enforce. ${ }^{8}$ To serve a judicial document upon a person resident in a foreign country, a Japanese court needs to act in accordance with the conventions or agreements concluded between Japan and the foreign county in question, such as the Hague Convention on Civil Procedure ${ }^{9}$ or the Hague Service Convention. ${ }^{10}$ Japanese courts never use means to serve judicial documents other than those permitted in the territorial foreign country in which the intended recipient resides.

Article 108 of the Code clearly provides that service of such documents in a foreign country shall be made as commissioned by the presiding judge to the competent government agency of that country or the Japanese ambassador, minister, or consul stationed in that country. This article provides only a general rule on service of process abroad, and a Japanese court needs to use methods permitted by the territorial foreign country where the intended recipient of judicial documents resides to avoid infringing its sovereignty.

7 Akira Kotera et al., Introduction to International LaW 講義国際法 162-3 (2d ed., 2013).

8 F. Mann, Studies in International Law 116-119 (1973). See also Restatement (Third) of Foreign Relations $\S 471 \mathrm{cmt}$. b (American Law Institute, 1987); G. Born \& P. Rutledge, International Civil Litigation in United States Courts 813 (4th ed. 2007); H. Nagel \& P. GotTwald, Internationales ZivilprozessRecht §7. 35 (7. Aufl. 2013).

9 Hague Convention on Civil Procedure, March 1, 1954, available at https://www.hcch.net/en/instruments/conventions/ full-text/?cid=33 (last visited on Oct. 31, 2016).

10 Hague Convention on the Service Abroad of Judicial and Extrajudicial Documents in Civil or Commercial Matters, Nov. 15, 1965, available at https://www.hcch.net/en/instruments/conventions. As other conventions, the Consular Convention between Japan and the United States of America, Mar. 22, 1963, and the Consular Convention between Japan and the United Kingdom of Great Britain and Northern Ireland, May 4, 1964 also provide a method for the service of process by consular officers, available at https://www.hcch.net/en/states/authorities/details3/?aid=261 (all last visited on Oct. 31, 2016). 
In the Code, the basic method for the service of process is koufu-soutatsu (交付送達, Personal service), which means that documents to be served are delivered directly to the intended recipients at their residence. ${ }^{11}$ The service can be implemented through delivery by either a court officer or post. However, regarding service of process by post, the employees of the Japan Post ${ }^{12}$ engaging in the service are regarded as public officials. ${ }^{13}$ Therefore, even if the service of process is implemented by post in Japan, the person engaging in the service is always a public official under Japanese law.

Consequently, if a Japanese court needs to serve a judicial document upon a person in a foreign country, it can never use a service of process by post. Service of process by post is regarded in Japan as based on the territoriality principle of jurisdiction to enforce, whose exercise outside Japan is prohibited.

\section{B. Service of Process by Foreign Courts to a Party Resident in Japan}

If applying the above reasoning to service of process by a foreign court to a person in Japan, the foreign court is required to follow the conventions and agreements concluded between the country of that court and Japan.

In this regard, the Japanese government has elucidated an official view concerning Article 6 (1) of the Hague Convention on Civil Procedure and Article 10 (a) of the Hague Service Convention. Both Conventions allow contracting States to send documents through postal channels directly to the persons concerned abroad. Japan does not object to use this method, but the government has clearly declared that "the no objection to the use of postal channels for sending judicial documents to persons in Japan does not necessarily imply that the sending by such a method is considered valid service in Japan; it merely indicates that Japan does not consider it as infringement of its sovereign power." ${ }^{, 14}$ It is clear that such a service of process

11 In this method, a person engaging in the service, such as a court official or an employee of Japan Post, needs to hand over judicial documents to the intended recipient and to obtain their seal or signature as proof of receiving the documents. The service has another method, whose name is Fu-yubin-soutatsu (付郵便送達, Service by Registered Mail), which involves service of process by registered mail. According to Article 107 (3) of the Code, fu-yubin-soutatsu is deemed to be made at the time when a court official sends the judicial documents. However, this method can be used only in exceptional circumstances, when a basic method of service, such as koufu-soutatsu, cannot be realized.

12 Japan Post Co., Ltd. is the main postal service company in Japan. It was established as a stock company in October 1, 2007 under the Japan Post Co., Ltd. Act (Act No. 100, 2005), by privatization of the national postal service business.

13 Article 74 of the Postal Act provides that yubin-ninsho-shi (郵便認証司: Official for certification of post) and persons engaging in the service of process by post shall be deemed to be public officials with regard to the application of the Penal Code or other penal provisions. Yubin-ninsho-shi is eligible to certify the delivery of service of process under Article 58(2) of the Postal Act. See Born \& Rutledge, supra note 8, at 828-9.

1428 I.L.M. 1558 (1989). According to the US Department of State's opinion, this statement was made following the US Department of State's encouragement for the Japanese government to clarify its position with regard to the service of 
does not infringe Japanese sovereignty, because Japan implicitly allows it by nonobjection. Nevertheless, the government provided an official view, clarifying that "the absence of a formal objection does not imply that the sending of judicial documents by postal channels to addressees in Japan is always considered valid service in Japan." 15 This statement is usually understood to mean that such a service of process does not necessarily fulfill the requirement of Article 118(ii) of the Code. Article 118 generally lays down the requirements for recognizing foreign judgments in Japan. In particular, item (ii) requires that the defeated defendant in the foreign litigation is properly served a summons or an order necessary for the commencement of the litigation. Therefore, service of process by post to a person resident in Japan from a court of a contracting State of the Hague Convention on Civil Procedure or the Hague Service Convention can be regarded as 'improper' under Article 118(ii), though allowed by those Conventions. E.g., in the judgment of the Hachioji Branch of Tokyo District Court on December 8, 1997 concerning litigation in the New York family court. the service of summons by post to a person resident in Japan was not recognized as a proper service under this article. ${ }^{16}$

From the official view of the Japanese government, one can infer that, were Japan to object to the articles of these two conventions, this would be premised on regarding the service of process by post to a person in Japan as an infringement of Japanese sovereignty. It is also reasonable to consider that, from the Japanese perspective, documents should be served in the territory of Japan through methods permitted therein, such as the methods permitted under conventions or agreements that Japan has concluded. The same rationale is employed in the judgment of the Supreme Court on April 28, 1998, ${ }^{17}$ with regard to Article 118(ii). In this case, recognition and enforcement of an order by the High Court of Hong Kong regarding the imposition

process in Japan by mail from another country party to the Hague Service Convention. See 30 I.L.M. 260 (1991). In Bankston v. Toyota Motor Corp., 888 F.2d 172 (8th Cir. 1989), it was discussed whether Article 10(a) of the Hague Service Convention permits service on a Japanese defendant by direct mail, and the subparagraph was interpreted as not permitting service by direct mail because the word 'send' is in the subparagraph, which is not the equivalent of 'service,' although the word 'service' is specifically used in other sections of the Convention. See HCCH, SERvice Handbook: Practical Handbook on the Operation of the Service Convention 87-91 (4th ed., 2016); Born \& Rutledge, supra note 8 , at 878 . However, in Japan, the subparagraph is usually understood as providing a formal method of service of process. See supra note 2, at 13.

15 See Paragraph 57 of Conclusions and Recommendations of the Special Commission on the practical operation of The Hague Apostille, Evidence and Service Conventions, available at https://assets.hcch.net/upload/wop/lse_conclee.pdf (last visited on Oct. 31, 2016). It is reported as the result of the Special Commission of HCCH held from October 28 to November 4, 2003. See HCCH, supra note 14, at 86.

16 Hachioji Branch of Tokyo District Court, Judgment, Dec. 8, 1997, 976 LAW TIMES REPORTS 判例タイムズ 253 (1998).

17 Supreme Court, Judgment, Apr. 28, 1998, 52(3) Supreme Court Reports (civil cases) 最高裁判所民事判例集 853 (1998). An English translation of the abstract of the judgment is available. See 42 JAPANESE ANN. INT'L L. 155 (1999). 
of litigation costs was argued. The service of process to notify the defendant of the commencement of proceedings was implemented through direct delivery by the plaintiff's attorney in the territory of Japan. The court adjudicated:

The service of process necessary to commence an action against defendants mentioned in Article 118(ii) of the Japanese Code of Civil Procedure does not have to be compliant with the laws and rules of our civil procedure. However, it is required that the process of service give the defendant actual knowledge of the commencement of action and not hinder the exercise of his/her right to defense. In addition, the viewpoint of realizing clear and stable procedures leads to the following interpretation of item (ii): where a treaty is concluded regarding judicial cooperation between our county and the judgment country for the service of judicial documents and it is required that the service of judicial documents necessary to commence an action be undertaken in accordance with the methods provided by that treaty, the service of process that does not abide by the methods of that treaty does not satisfy the requisite mentioned in Article 118(ii).

Service of process through a direct delivery by the plaintiff's attorney is not permitted by the Hague Service Convention, to which Japan and the UK - which had sovereignty over Hong Kong when the documents were served-are parties. The Consular Treaty between Japan and the $\mathrm{UK}^{18}$ does not permit such service, either. Therefore, the service was held to be unlawful.

However, there are some cases in which Japanese courts have allowed for the recognition of foreign judgments despite service of process not being effected through methods permitted in conventions or agreements concluded by Japan. Article 118(ii) also provides that its requirement is fulfilled if the defeated defendant responds to the original foreign action, even though the service of process does not comply with those agreements. In the above-mentioned judgment by the Supreme Court, e.g., the Hong Kong judgment fulfilled the requirement of Article 118(ii) because the defendant responded to the plaintiff's action and appeared at the Hong Kong proceedings.

18 Consular Convention between Japan and the United Kingdom of Great Britain and Northern Ireland, May 4, 1964. Article 25 of the Convention allows consular officers to serve judicial documents on behalf of the courts of the sending State provided that it is in accordance with the law of the sending State and not inconsistent with the law of the receiving State. 


\section{Analysis}

How should we understand Japanese state practice regarding the relationship between service of process and sovereignty? In particular, it should be explained how one can understand the contradiction that a foreign judgment whose service of process would infringe Japanese sovereignty, can be recognized and enforced in Japan.

From a Japanese perspective, judicial documents should be generally served through methods permitted by the rules of the territorial country where service is actually carried out. If a method is not in accordance with a territorial country's rules, it can be regarded as an infringement of sovereignty. However, it should be confirmed why a country condemns this as an infringement of sovereignty. Theoretically, a country will always argue against every infringement of its sovereignty because it always wants to maintain that sovereignty. However, this explanation is meaningless because sovereignty does not exist for itself; rather, it has to exist for a concrete purpose. As for service of process, Japanese sovereignty over its territory has to exist to realize the procedural protection of persons resident in the territory of Japan. Japan needs to claim infringement of its sovereignty only when a service of process method for foreign proceedings is neither permitted in Japan, nor can it properly protect the procedural rights of a person who will be served there. It does not have to claim infringement with respect to service of process giving people in Japan proper procedural protection from the Japanese perspective.

Based on this reasoning, it is understandable why the Japanese courts only use methods permitted by conventions or agreements concluded between Japan and the country where judicial documents are to be served. Japan actively tries not to infringe other countries' sovereignty. The best way to avoid encroaching on their sovereignty is to adopt the methods of service of process that the territorial country clearly permits through conventions or agreements. A method that is not clearly permitted by the territorial country can be used if the territorial country does not condemn it as an infringement of sovereignty. However, it is not necessary for a Japanese court to use those methods.

Regarding service of process in Japan for foreign proceedings, in general, Japan regards the service of process in its territory as infringement of sovereignty unless its method is clearly permitted. Nevertheless, Japan does not claim the infringement of its sovereignty if the method properly protects the procedural rights of the person to be served. Therefore, even if the service of process upon a defendant employs a method not clearly permitted in Japan, a foreign proceedings' judgment can be recognized and enforced if the method gives the defendant proper procedural 
protection, which is proved by the defendant's response to the foreign action under Article 118 (ii) of the Code.

\section{Contemporary Issue: Service by Electronic Means}

Recently, in some jurisdictions, the service of process can be effected by electronic means, such as email. ${ }^{19}$ Japanese courts do not currently use electronic means for service of process, and it is presumed that they will continue not to use it in the near future, as the service of process by electronic means is quite different from the basic method of koufu-soutatsu.

Conversely, it is feasible for judicial documents to be served by electronic means upon a person resident in Japan. According to the above-mentioned Japanese state practice, Japan would theoretically regard this as an infringement of its sovereignty. However, if a defendant receiving the service by email can actually respond to the foreign proceedings, Japan would not claim an infringement of sovereignty, and consequently, the judgment in the foreign proceedings can be regarded as fulfilling the requirement of Article 118(ii).

\section{Taking Evidence Abroad}

\section{A. Taking Evidence Abroad by a Japanese Court}

Taking evidence by courts is also regarded as an exercise of jurisdiction to enforce in Japan. $^{20}$ Therefore, Japanese courts conduct judicial acts that abide by the principle of 'territoriality' not to infringe foreign sovereignty.

However, there are only a few cases in which Japanese court invoked international judicial assistance based on conventions or agreements, such as the Hague Convention on Civil Procedure. ${ }^{21}$ If a Japanese court tries to examine a witness in a foreign country, it would ask the witness to attend the proceedings voluntarily. More precisely, a

19 HCCH, supra note 14, at 180-99.

20 Ichiro Kasuga, International Judicial Assistance for Taking and Examination of Evidence 証拠収集及び証拠調 べにおける国際司法共助-執行管轄権の視点を交えて一, in THEORY OF CIVIL Procedure IN CASE LAW (vol. 2) 判例民事訴訟法の理論(下) 425 (Kouji Shindo et al., 1995). See also Mann, supra note 8, at 119-20; BoRN \& RutLEDGe, supra note 8, at 910-2.

21 There were reportedly only five times in 2011 when Japanese courts requested of other countries the taking of evidence for cases in civil or commercial matters. Regarding requests for the examination of witnesses to other countries, there was only one case between 2002 and 2011. See supra note 2, at 448. 
party who considers it necessary to examine the witness asks them to come to Japan, and after the witness arrives into the territory of Japan, the court serves a writ of summons, in the same way as that used for purely domestic cases. ${ }^{22}$ Consequently, Japanese courts rarely engage directly in taking evidence abroad, and sovereignty related problems do not appear with regard to Japanese proceedings.

Nevertheless, there was a recent noteworthy case on the taking of evidence abroad. The Tokyo District Court on July 27, 2015 ordered a Korean company, defendant in the litigation to produce documents. ${ }^{23}$ The plaintiff, a Japanese company, sued for compensation for losses arising from unauthorized use of the plaintiff's trade secrets. During this litigation, the plaintiff also applied for an order for the production of documents held by the defendant in Korea. Although there were no arguments in the decision regarding the relationship between Korean sovereignty and the production of documents, the court is inferred to have considered ordering a foreign defendant to produce documents held in the foreign country of residence not to constitute an infringement of sovereignty. While this is only one case of Japanese state practice, it should be highlighted because a Japanese court made an order against a foreign company through the indirect enforcement measure provided in Article 224 of the Code, which provides that, if the party does not follow the order, the court may recognize the opponent party's allegations concerning the contents of the documents, as true.

\section{B. Taking Evidence in Japan for Foreign Proceedings}

If a foreign court wants to take evidence in Japan, it should either be in accordance with the Hague Convention on Civil Procedure or other treaties concluded by the forum state and Japan, or directly ask the Japanese government through diplomatic channels. It should be noted that Japan is not a contracting party to the Hague Evidence Convention. ${ }^{24}$

Japan is strictly abiding by the principle of territoriality. It can be recognized from the information regarding depositions in Japan for the US court proceedings. Pursuant to Article 17(e) of the Consular Convention between Japan and the US, both mutually permit a consular officers of the other party within his/her consular district to "take depositions, on behalf of the courts or other judicial tribunals

22 Nozomi Tada, International Judicial Assistance in the Taking of Evidence Abroad in Civil or Commercial Matters 国際民事証拠共助法の研究 85 (2000).

23 Tokyo District Court, Order, July 27, 2015, 2280 LAw CASES REPORTS 判例時報 120 (2016).

24 Hague Convention on the Taking of Evidence Abroad in Civil or Commercial Matters, Mar. 18, 1970, available at https://www.hcch.net/en/instruments/conventions/status-table/?cid=82 (last visited on Oct. 31, 2016). 
or authorities of the sending state, voluntarily given" and to 'administer oaths.' Consular officers can take evidence from "any persons in the receiving state in accordance with the laws of the sending state and in a manner not inconsistent with the laws of the receiving state." The Japanese government seems to recognize that this method alone is permitted in Japan to take depositions for the US court proceedings. Accordingly, other extraterritorial methods, such as an attorney taking depositions for the US proceedings outside the consular district, e.g., in a hotel room, through voluntary cooperation of the defendant is prohibited in Japan as an infringement of Japanese sovereignty. ${ }^{25}$ The official websites of both the US Department of State ${ }^{26}$ and the US embassy in Tokyo provide information on depositions in Japan. ${ }^{27}$ On depositions outside the consular district, it states as follows:

Japanese law and practice, and the mutually agreed upon interpretation of the U.S. Japan bilateral Consular Convention concerning obtaining evidence in Japan permits the taking of a deposition of a willing witness for use in a court in the United States only: 1. if the deposition is presided over by a U.S. consular officer (if the deposition is presided over by a U.S. consular officer (in order for the consular officer to preside over the deposition, it must be conducted in the English language); 2. is taken pursuant to an American court order or commission; 3. and if any non-Japanese participant travelling to Japan applies for and obtains a Japanese Special Deposition visa.

Furthermore, it is highlighted that:

Japanese authorities have informed the United States that Articles 3 and 72 of the Japanese Lawyer Law ${ }^{28}$ may prohibit the taking of depositions in Japan outside the procedures established for taking consular depositions under Article 17 of the U.S. Japan bilateral Consular Convention by private attorneys not admitted to practice law in Japan.

Inferring from this information, the Japanese authorities would strictly maintain the principle of territoriality regarding depositions in Japan. Even if persons in Japan

25 Born \& Rutledge, supra note 8, at 912-9.

26 U.S. Department of State Bureau of Consular Affairs, Legal Considerations: Japan, available at https://ravel.state.gov/ content/travel/en/legal-considerations/judicial/countryjapan.html (last visited on Oct. 31, 2016).

27 Embassy of the United States to Japan, Depositions in Japan, available at https://japan.usembassy.gov/e/acs/tacs-7116. html (last visited on Oct. 31, 2016).

28 Attorney Act 弁護士法 (Act No. 205, 1949). 
are willing to voluntarily cooperate with foreign proceedings, the authorities will not permit them to do so as long as the taking of evidence is actually conducted in Japan.

\section{Analysis}

As shown above, Japan is strictly abiding by the principle of territoriality. Japanese courts rarely engage in taking evidence abroad. Even if the courts need to do this, they shall follow those international conventions or agreements in practice. Conversely, Japan seems to forbid any method for the taking of evidence in its territory for foreign proceedings unless obviously permitted. Therefore, getting a Japanese court order for a foreign party to produce documents held in the foreign country of residence is quite remarkable. It means that a Japanese court would exercise jurisdiction to enforce to foreign residents, i.e., those residents outside the territory of Japan, if they are parties to Japanese proceedings.

However, it is also recognized that depositions for the US court proceedings are actually taken by private attorneys outside the consular district in Japan. The Japanese Ministry of Foreign Affairs reportedly complained to the US Consul General, Osaka-Kobe in a case where a deposition was taken in a hotel room in Osaka. ${ }^{29}$ Faced with these actual situations, what Japanese authorities can do, other than complain, is to refuse recognition and enforcement of foreign judgments in whose proceedings such illegal depositions are conducted. Article 118 of the Code provides that a foreign judgment shall not be recognized in Japan if its contents or proceedings are contrary to Japanese public policy. To date, no such cases have been reported in the Japanese case report journals, but the possibility of such a case in the future cannot be ruled out. In deciding whether particular foreign proceedings in which depositions are taken in such a manner are contrary to Japanese public policy, a Japanese court should consider the meaning of sovereignty. In this respect, sovereignty exists to protect people in Japan from foreign judicial acts unfamiliar to them. Therefore, in some cases, if persons voluntarily cooperate with the taking of their depositions, it may be unnecessary to deny recognition of foreign judgments because of the infringement of Japanese sovereignty by illegal depositions. ${ }^{30}$

29 Takeo Kosugi, America no “Discovery” Issues of Depositions of USA in Japan アメリカの「ディスカバリー」の日本 での実施をめぐる問題点, in International Civil Procedure 国際民事訴訟法 244 (A. Takakuwa \& M. Dogauchi eds., 2002).

30 Id. at 248. See also Hideyuki Kobayashi and Masako Murakami, International Civil Procedure 国際民事訴訟法 131 (2009). 


\section{Use of New Technologies for Taking Evidence Abroad}

Recently, some countries have adopted newer methods of taking evidence abroad for their court proceedings such as taking testimony via video-link. ${ }^{31}$ As noted above, Japan has not adopted such methods for taking evidence abroad. Nevertheless, a foreign court may invoke these new technologies to take evidence from a person residing in Japan. ${ }^{32}$ Therefore, it is necessary to discuss whether such methods of taking evidence should be permitted from the Japanese perspective, although there has been almost no discussion in Japan regarding this issue to date.

Taking evidence via video-link is quite similar to the usual procedure for that in Japan. Although there can be no judicial officers and attorneys presiding over the judicial act in the territory of Japan, persons who experienced evidence-taking in such a manner do exist in Japan and Japanese sovereignty needs to protect them from foreign judicial acts that are unfamiliar to them. Therefore, taking account of the above Japanese state practice, it can be reasonably inferred that Japanese authorities would object to taking evidence in such a manner because there is no convention or agreement in which Japan permits evidence to be thus taken.

However, this method is usually adopted complementarily to the traditional methods of taking evidence based on practical considerations and/or considerations of justice, ${ }^{33}$ and these methods may usually be invoked for the convenience of the person giving evidece. Further, telecommunication technologies can be said to render meaningless the physical location of the person giving evidence. Considering these factors, as one of the most developed countries in terms of telecommunications, Japan may permit foreign courts to take evidence from persons residing in its territory through new technologies if the person is willing to cooperate in the foreign proceedings.

$31 \mathrm{HCCH}$, supra note 3, at 231-4. The use of video-link and other modern technologies in the taking of evidence abroad is discussed at HCCH. The meeting of experts' group on the issue was held on December 2-4, 2015. See HCCH, Report of the Experts' Group on the Use of Video-Link and Other Modern Technologies in the Taking of Evidence Abroad, available at https://assets.hcch.net/docs/20ba36d9-3aa9-45ff-b82b-4ead24db148c.pdf (last visited on Oct. 31, 2016).

32 A case was reported where a Japanese party and an attorney were examined in a meeting room in Japan for a foreign proceeding through Skype. See supra note 1, at 18.

33 Supra note 2, at 231. 


\section{Sovereignty and National Civil Procedure}

\section{A. Discussions by Lawyers in Japan}

As detailed above, Japan relatively strictly abides by the principle of territoriality. Japanese scholars have discussed the kind of judicial acts by courts that may constitute infringement of foreign sovereignty. Their arguments are almost in line with the current Japanese state practice.

Before analyzing discussions in Japan, the necessity of dividing judicial acts by courts into two categories should be identified. The first is a judicial act that involves a certain performance of official acts ${ }^{34}$ in foreign countries, such as service of process abroad and depositions in foreign countries other than the forum country. The second is a judicial act in which a court orders or requests something to a person in territories of countries other than the forum country, such as an extraterritorial order for production of documents against a person resident in a foreign country. Although both are regarded in Japan as the exercise of jurisdiction to enforce, they should be treated differently in that the former includes the actual performance of official acts in the territory of another country. It is a traditionally and firmly established principle that the jurisdiction to enforce involving such a performance cannot be exercised in another county without its consent. ${ }^{35}$ Therefore, such exercise of jurisdiction should be treated differently from the others.

Regarding judicial acts involving the performance of official acts in the territory of another country, Japanese scholars reaffirm the Japanese authorities' stance, holding strictly the traditional principle of territoriality: in the absence of consent, a state thus cannot exercise jurisdiction to enforce with physical force within the territory of another state. They regard it as illegal to take depositions in Japan for the US court proceedings when this is not based on Article 17 of the Consular Convention. ${ }^{36}$ Some scholars argue that taking voluntary depositions through a private attorney for US court proceedings should not be regarded as an infringement of Japanese sovereignty. ${ }^{37}$ However, even if they are presided over by a private attorney, the character of the deposition in Japan as an exercise of jurisdiction to

\footnotetext{
34 Mann, supra note 8, at 114-6.

35 Id. at 137. See also Restatement (Third) of Foreign Relations 526; NAGEL \& GotTwaLd, supra note 8, §7. 35-36.

36 See Kasuga, supra note 20, at 457; Kosugi, supra note 29, at 244-5; Kobayashi \& MuraKami, supra note 30, at 131.

37 Takao Sawaki \& Masato Dogauchi, Introduction to Private International Law 国際私法入門 325-6 (2012).
} 
enforce does not change. ${ }^{38}$ In addition, the will of the private person from whom evidence is taken cannot be cure the infringement of Japanese sovereignty. ${ }^{39}$ Considering these points, the prevailing view is to regard these actions as illegal according to the rules of public international law.

Conversely, regarding extra-territorial orders or requests to persons in a foreign country, Japanese positions can be summarized in the following three points. ${ }^{40}$ First, requesting voluntary cooperation in Japanese civil procedure to a person in a foreign country, such as a commission of expert testimony, does not constitute infringement of territorial sovereignty of the country where the recipient resides. ${ }^{41}$ Second, a court order to a person in a foreign country does not raise an issue of infringement of foreign sovereignty if that person is a party to litigation in the forum country because the sanction to that person for non-obedience is only the recognition that their opponent's allegations concerning the matters for examination are true. ${ }^{42}$ Third, Japanese courts cannot issue an order of or against a person in foreign country if that person is not a party to Japanese proceedings because the sanction for non-obedience is a fine. In this case, the court cannot exercise jurisdiction to enforce, as it involves punishment outside the territory of Japan. These are argued from the perspective of legality in public international law.

\section{B. Ambiguity of Rules in Public International Law}

The author opines that there is a problem in these discussions in Japan. Although they have invoked the rules of public international law, general state practices in the contemporary world have not been well analyzed. In other words, the legal grounds of their arguments based on public international law are not clear. ${ }^{43}$ In addition, as

38 The characterization of such acts can be different from country to country. It would be reasonable to determine the character of a specific act according to the law of the territory in which the act is conducted. Therefore, at least in Japan, depositions are characterized according to Japanese law. From its perspective, they are also regarded as the exercise of jurisdiction to enforce, even if presided over by private attorneys. For details on argument against this view, see H. Smit, International Cooperation in Civil Litigation: Some Observations on the Roles of International Law and Reciprocity, 9 Neth. InT'L L. Rev. 137 (1962).

39 See Kasuga, supra note 20, at 457; Kosugi, supra note 29, at 245. See also M. Akehurst, Jurisdiction in International Law, 46 BRIT. Y.B. InT'L L. 147 (1972-3).

40 Kasuga, supra note 20, at 458-64. See also Takeo Kosugi, Examination of Evidence in Foreign Country 外国での証 拠調べ, in TAKaKuWa \& Dogauchi, supra note 29, at 217-29.

41 It is argued that a Japanese court can designate an expert witness in foreign countries to give expert testimony without infringing the territorial sovereignty under Article 213 of the Code, because no sanctions for non-compliance are provided in the Code. See Kosugi, supra note 40, at 221.

42 Akehurst, supra note 39, at 178.

43 Faced with the discussions between the US and European countries, it is reasonable to recognize that there are no clear 
theoretical discussions, their arguments on orders and requests to persons abroad would have two points that need to be further explained.

First, why the voluntary cooperation of persons abroad can solve problems regarding the infringement of foreign sovereignty needs to be further explained. ${ }^{44}$ Private persons' will does not change the character of the judicial acts. It is usually recognized that judicial acts involving a certain performance of official acts, such as service of process, cannot be conducted abroad even if the person in the foreign territory voluntarily accepted the acts. Logically, the same must be true for extraterritorial orders and requests to a person resident in a foreign country. Therefore, at the very least, an explanation for the different treatment is necessary.

Second, the distinction between parties to the court procedure and third parties should also be explained. It may be arguable whether it is possible to order nonparty witnesses who are closely related to parties, such as a foreign subsidiary or a foreign parent company of a defendant company, to testify. ${ }^{45}$ The grounds of the clear distinction in public international law could be the difference in sanctions for non-obedience in Japan. If a party to proceedings does not obey, the sanction is the court's recognition that the opponent's allegations concerning the matters for examination are true, which is only an issue of the finding of facts in the proceedings. Conversely, if a third party objects to the order, the sanction may be the impostion of fine on the third party, which may be criminal or non-criminal. ${ }^{46}$ However, both sanctions are indirect enforcement measures, whose actual influence as compulsion may not be so different. ${ }^{47}$ Eventually, the grounds for the distinction under public international law are not clear.

In the author's view, the problem of international law regarding the relationship between sovereignty and judicial acts by courts is the conflict of the jurisdiction to enforce between the forum state and the territorial state where the person resides. ${ }^{48}$

rules of customary international law on the limits of the jurisdiction to enforce. See J. Crawford, Brownlie's Principles of Public International Law 480 (8th ed. 2012).

44 TADA, supra note 22, at 86.

45 Born \& RutLedge, supra note 8, at 930-1. Mann, Further Studies in International Law, 40-51.

46 For example, a non-criminal fine of not more than 200,000 Japanese yen may be imposed for non-compliance with orders for production of documents, pursuant to Article 225(2) of the Code. Simultaneously, a criminal fine of not more than 100,000 Japanese yen may be imposed for non-compliance with orders for production of documents without reasonable grounds, pursuant to Article 229(5) of the Code.

47 While the jurisdiction to enforce for criminal sanctions is considered as relatively strictly territorial (Restatement (Third) of Foreign Relations $\S 432 \mathrm{cmt}$. b; Akehust, supra note 39, 152.), it may be possible to impose non-criminal fine on a person abroad if the person has a real and substantial connection to the forum country. See TADA, supra note 22, at 97-8.

48 See Restatement (Third) of Foreign Relations $\S 442$; Born \& RutLedGe, supra note 8, at 941-62. 
It would be reasonable to consider that, as a general principle, the territorial state's jurisdiction prevails over that of the forum state. However, given the ongoing lack of the clarity in the precise rules for reconciling the two jurisdictions through international law, each country is currently required to determine autonomously how to effect this reconciliation. ${ }^{49}$ The customary rules of public international law are clarified based on those State practices. ${ }^{50}$ Therefore, discussions in Japan seem to lack a firm basis in public international law.

In considering these points, it would be better for each country to argue not the precise rules of public international law but rather its own policy on international judicial acts. Considering the traditional principle of the territoriality of the jurisdiction to enforce, it should be taken as premise that territorial jurisdiction prevails over forum jurisdiction. Therefore, it is critical to discuss the extent to which the territorial State should endure orders to its residents by foreign courts to determine the point of balance between the two jurisdictions. ${ }^{51}$ E.g., Japan should consider, first, the extent to which it can permit foreign courts to conduct judicial acts related to people resident in Japan, and then, based on the principle of equality, it should be determined to what extent Japanese courts can conduct judicial acts abroad.

\section{Japanese Policy of Judicial Acts Abroad}

As for the Japanese policy of judicial acts abroad, Japanese lawyers' arguments can be said to be reasonable and moderate. Regarding judicial acts involving the performance of official acts, it may be convincing to adhere strictly to the principle of territoriality in order to protect people within the territory of Japan from foreign judicial acts that are unfamiliar to them. ${ }^{52}$ The policy on extra-territorial orders by a foreign court of or against persons in Japan can be determined differently because of the non-existence of the performance of official acts in its territory. If a person in Japan voluntarily cooperates with foreign proceedings without compulsion, there would be no reason for Japan to claim an infringement of sovereignty, because

\footnotetext{
49 The role of national conflicts rule should be highlighted. For details on the roles of public and private international law, see A. Bianchi, Comment, in Extraterritorial Jurisdiction in Theory and Practice 74-101 (K. Messen ed., 1996); K. Messen, Drafting Rules on Extraterritorial Jurisdiction, Messen, $i d$. at 226-7.

50 Nagel \& Gottwald, supra note 8, § 7: 45-46. See also H. Maier, Jurisdictional Rules in Customary International Law, Messen, $i d$. at 64-74.

51 ManN, supra note 8, at 112.

52 If a state wishes to avoid international criticism over its exercise of extra-territorial jurisdiction, it is better to adhere to the principle of territoriality. See CRAWFORD, supra note 43, at 486 .
} 
Japanese sovereignty exists not for its own sake but for the protection of people in Japan. Provided the forum country is appropriate for dispute resolution from the Japanese viewpoint, ${ }^{53}$ orders by the presiding foreign court to the litigation parties should be permitted by Japan to realize fair justice, unless the orders conflict with Japanese law. ${ }^{54}$ Regarding orders by a foreign court to a person in Japan who is not a party to proceedings, these may be denied if one interprets strictly the traditional principle of territoriality on criminal jurisdiction to enforce, as lawyers in Japan have discussed.

However, this policy may be seen as too restrictive. It is also possible for Japan to adopt a more liberal and tolerant policy. E.g., Japan could permit foreign countries to conduct judicial acts with a performance of judicial acts on Japanese territory on condition that the person targeted by the judicial acts voluntarily cooperates with the foreign proceedings. It is also possible to permit a foreign court to issue an order to a person in Japan who is not a party to proceedings under the sanction of a noncriminal fine, provided the forum is appropriate from the Japanese perspective and the order to the person is necessary to the fair settlement of the dispute.

Regarding new technologies, it may be better for Japan to permit foreign courts to serve documents via email upon or to take evidence via video-link from a person in Japan on condition that the person chooses to cooperate with such a method of their own free will. They may choose to use them for their convenience. Instead of travelling to the forum country to give testimony, a person may use these technologies for the same purpose. It seems unnecessary to claim an infringement of sovereignty for those judicial acts, provided the persons in Japan voluntarily cooperate with the foreign proceedings and the methods used do not contravene any Japanese law.

53 It should be determined by the Japanese rules of indirect grounds of jurisdiction for recognition of foreign judgments. See Masato Dogauchi and Hiromasa Furuta, 1497 Jurisuto [Jurist] 66 (2016). As introductory remarks for a note on the Order of Tokyo District Court on July 27, 2015, they pointed out that the possibility of the order of production of documents should be further discussed in cases where the direct grounds of jurisdiction is contested. See Madoka Shimada, 1497 JuRISUTO [Jurist] 67 (2016).

54 E.g., if Japanese law, such as the Act on the Protection of Personal Information (Act No. 57, 2003), forbids the provision of the information, the extra-territorial order for the production of such information by foreign courts cannot be permitted. For details on the discussions of the US extraterritorial discovery, see BoRN \& RUTLEDGE, supra note 8, at 941-62. 


\section{Conclusion}

In this time of globalization, discussions regarding sovereignty tend to minimize its meaning. Nevertheless, there is also a firm belief that sovereignty continues to exist, and the infringement of sovereignty is a highly critical point of contention. In considering this issue, the meaning of sovereignty should be reconsidered in order to adjust it to the current situations. Sovereignty does not exist for its own purpose, but rather for the benefit of the people in that country. If Japan wants to protect people in its own territory, it would be better to conclude more treaties and conventions, such as the Hague Evidence Convention, ${ }^{55}$ than to regard an act of foreign proceedings as an infringement of its sovereignty. If Japan adopts a policy more tolerant of other countries' judicial acts, this would be conducive to better justice in transnational civil and commercial dispute settlements.

55 Considering the US court stance of 'non-exclusivity' of the Hague Evidence Convention, questions on the US extraterritorial discovery will not be solved even if Japan concludes the Hague Evidence Convention. However, it will contribute to the gradual development of the Japanese circumstances of international judicial assistance. See TADA, supra note 22, at 206. 